Gut, 1987, 28, S1, 15-17

\title{
Growth stimulating activity associated with an altered cell renewal pattern in the small intestine
}

\author{
VIJAY L GREY, JEAN-MICHEL KENSCOFF, AND CLAUDE L MORIN \\ From the Centre de Recherche Pédiatrique, Hôpital Ste-Justine, and Département de Pédiatrie, Université de \\ Montréal, Montreal, Quebec, Canada
}

SUMMARY A growth stimulating activity has been recently identified in the rat proximal intestine during the transient stages of adaptation after small bowel resection. This study shows that the growth stimulating activity is associated with all the cells of the crypt-villus axis. At the same time the thymidine kinase activity is detectable in all the cells implying a more extensive proliferative zone during the transient stages of adaptation. The presence of the growth stimulating activity along with the more extensive proliferative zone suggests that the activity modulates the proliferation capacity of intestinal epithelial cells.

The epithelial cells of the small intestine are a renewing cell population characterised by segregation of the proliferative zone in the crypts and a mature differentiated zone in the villus cells. These cells have a rapid turnover and an equilibrium exists between cells produced in the crypt and cells lost at the villus tip. This equilibrium is altered by a small bowel resection. After resection there is an increase in cell proliferation in the remnant small intestine and a resultant adaptive hyperplasia when a new steady state is reached. ${ }^{1}$ A growth stimulating activity has been identified from the rat proximal intestine after a $50 \%$ small bowel resection, and this could play a role in the observed adaptive response. ${ }^{2}$ This activity was detectable in resected animals $48 \mathrm{~h}, 72 \mathrm{~h}, 96 \mathrm{~h}$ but not at eight days after resection when presumably a new steady state is reached. Normal animals fed ad libitum do not show this activity. In this study the distribution of the stimulatory activity along the crypt-villus axis of male Sprague-Dawley rats was examined four days after small bowel resection to ascertain whether it is associated with proliferating cells or with differentiated villus cells.

\section{Methods}

SURGERY

Proximal small intestine was obtained from $150 \mathrm{~g}$ male Sprague-Dawley rats (MacDonald Farm, StAnne de Bellevue, Que) after a $50 \%$ small bowel

Address for correspondence: Dr V L Grey, Hôpital Sainte-Justine, 3175 Cote Sainte-Justine, Montreal, Quebec H3T IC5, Canada. resection, carried out as previously described. ${ }^{2}$ The animals were fed orally with a regular diet.

\section{CELL ISOLATION}

Four days after surgery the resected animals were killed by decapitation and the proximal small intestine removed for experimentation. The intestine was rinsed with saline, one end tied off with 4-0 surgical thread and everted. The everted intestine was rinsed in $\mathrm{Ca}^{++} / \mathrm{Mg}^{++}$free Dulbecco's phosphate buffered saline containing aprotinin $(10 \mathrm{U} / \mathrm{ml})$, cut into approximately $5 \mathrm{~cm}$ pieces, and transferred to an Erlenmeyer flask containing $\mathrm{Ca}^{++} / \mathrm{Mg}^{++}$free Dulbecco's phosphate buffered saline $(2.5 \mathrm{ml} / 5 \mathrm{~cm}$ intestine), $1.5 \mathrm{mM}$ ethylenediamine tetraacetate, $0.5 \mathrm{mM}$ dithiothreitol, and aprotinin $(10 \mathrm{U} / \mathrm{ml})$. The tissue was incubated for different times at $37^{\circ} \mathrm{C}$ under gentle shaking $(110 \mathrm{rpm})$ in a New Brunswick water bath. Thus, sequential fractions of isolated cells were obtained. The different cell fractions were centrifuged at $1000 \mathrm{rpm}$ for three minutes and the pellet washed twice with $\mathrm{Ca}^{++} / \mathrm{Mg}^{++}$free Dulbecco's phosphate buffered saline containing aprotinin. ${ }^{3}$

\section{PREPARATION OF THE GROWTH STIMULATING} FRACTION

The growth stimulating fraction was prepared from the sequential fractions as described previously. ${ }^{2}$ The cells were suspended in $2 \times$ volumes of water, immersed in a boiling water bath for five minutes and homogenised. The supernatant was discarded and the precipitate extracted with cold $0 \cdot 1 \mathrm{~N} \mathrm{HCl}$. The extract 
was centrifuged at $9000 \mathrm{~g}$ for $40 \mathrm{~min}$ and the supernatant kept. A further purification of the extract, by binding to CM-Sephadex $\mathrm{C}-25$ at $\mathrm{pH} 4.8$ then eluting with $0.01 \mathrm{~N} \mathrm{HCl}, 1 \mathrm{M} \mathrm{NaCl},{ }^{4}$ was used in these experiments. The protein content was determined by measuring the absorbance at $275 \mathrm{~nm}$ and using $E_{275}=6.0$ for bovine serum albumin. ${ }^{5}$

IN VITRO ASSAY OF DNA SYNTHESIS BY THE

GROWTH STIMULATING FRACTION

The stimulation of DNA synthesis was quantified by measuring the rate of incorporation of thymidine into DNA of mouse intestinal explants maintained in organ culture as previously described. ${ }^{2}$ One unit of stimulation is defined as the stimulation index above control per $\mu \mathrm{g}$ protein in the growth stimulating fraction.

ENZYME ASSAY

Thymidine kinase in the cell fractions was measured according to the method described by Klemperer and Haynes $^{6}$ except that the product was isolated using DEAE impregnated paper discs (Whatman DE-81) according to the method of Breitman. ${ }^{7}$ Enzyme activity is the cpm/thymidine monophosphate/g protein $/ \mathrm{min}$. Alkaline phosphatase was determined according to the method of Eicholz. ${ }^{8}$ The specific activity is the micromoles $\mathrm{p}$-nitrophenol/g protein/ $\min$. The protein content in the cell fractions was determined by the method of Lowry. ${ }^{9}$ The percentage of cells isolated in each successive cell fraction was determined by the protein content in the given fraction.

\section{Results}

The results shown in Fig. 1a indicate that the growth stimulating activity is distributed throughout the crypt villus axis. At the same time, thymidine kinase activity is detectable in all the fractions implying that all the cells along the crypt villus axis are proliferating (Fig. 1b). A comparison of normal animals with four day resected animals shows that at any given point the thymidine kinase activity is at least four-fold greater than in the controls, whereas, the alkaline phosphatase distribution is not markedly different.

The growth stimulating activity is known to be present in the proximal small intestine for a limited time, four days, after a $50 \%$ small bowel resection. ${ }^{2}$ The results in Fig. 2 show that the levels of thymidine kinase are raised throughout the crypt villus axis for the same time period, two and four days postresection. When the activity is diminished at eight days a new steady state is reached and the thymidine kinase distribution (Fig. 2) changes to resemble that of the intestine from normal animals.
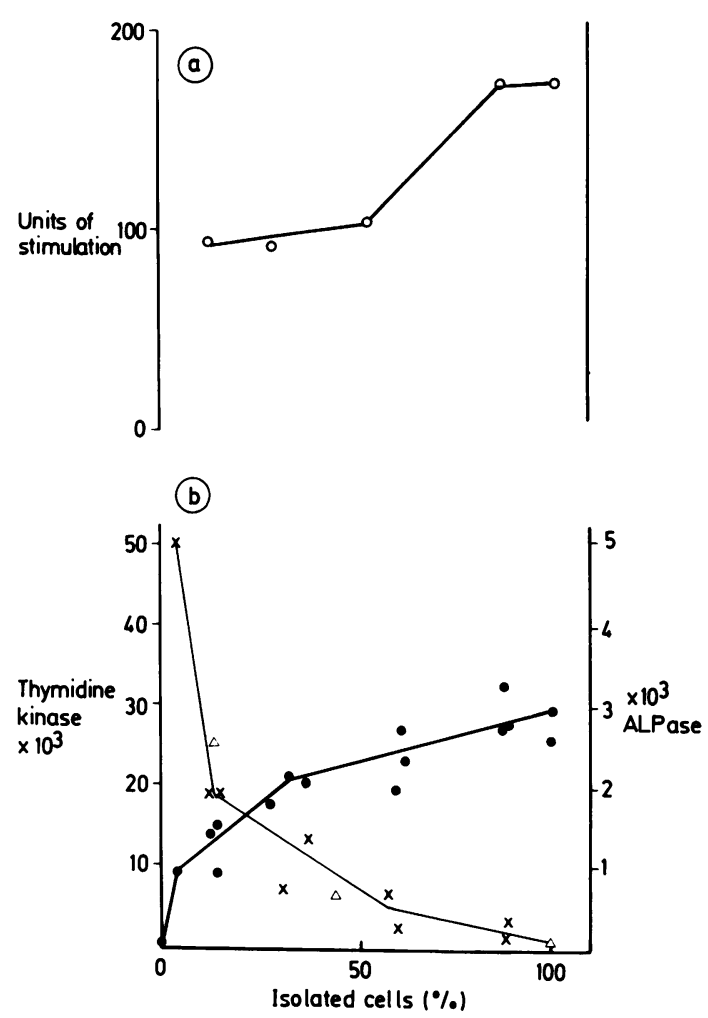

Fig. 1 Distribution of (a) growth stimulating activity and (b) marker enzymes (- thymidine kinase, $x-x$ alkaline phosphatase) along the crypt villus axis of the proximal small intestine after a small bowel resection, at four days. The open $\triangle$ show the alkaline phosphatase activity from normal animals. One unit of stimulation is defined as the stimulation index above control/ $\mu \mathrm{g}$ protein of growth stimulation fraction tested with the assay. The thymidine kinase activity is the cpm thymidine monophosphate/g protein/min. Alkaline phosphatase activity is the p-nitrophenol $\mu \mathrm{mol}$ produced $/ \mathrm{g}$ protein $/ \mathrm{min}$.

\section{Discussion}

In the intestine it is generally accepted that proliferation takes place in a discrete crypt cell compartment and as the cells migrate up towards the lumen they differentiate and lose their capacity to proliferate. Immediately after a resection there is a rapid increase in proliferation ${ }^{10}$ before a new steady state is established with an increase in crypt depth and villus height. This new steady state is reached within eight days after a $50 \%$ jejunal resection in the rat. The growth stimulating activity is also present during this period of transition ${ }^{2}$ and the results shown here suggest that it is associated with a more extensive proliferative zone identified by thymidine kinase 


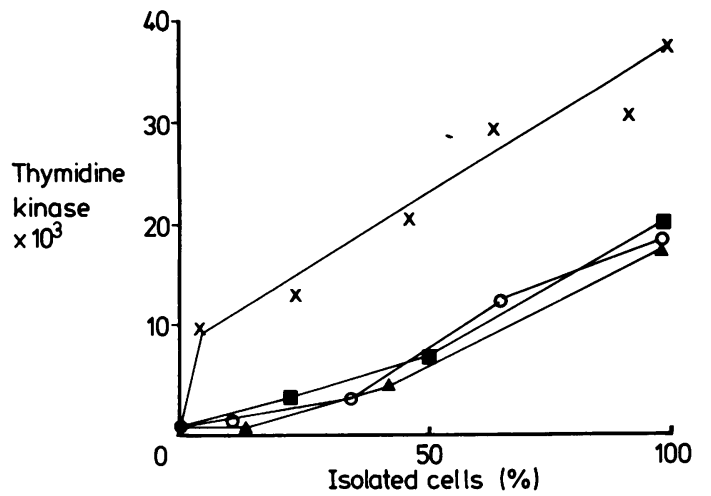

Fig. 2 Distribution of thymidine kinase activity in normal animals $(\triangle)$ and resected animals $2(\times), 6(\square)$, and 8 (O) days postresection. Normal animals were fed ad libitum. The same portion of intestine was taken from the two and eight days animals as described above for the four day postresection animals. A similar portion was studied in the normal animals.

activity. When the activity is no longer present (at eight days after resection) distribution of the thymidine kinase activity resembles that of normal animals. ${ }^{11}$

The intestinal epithelium manifests a basic pattern of cell proliferation and then differentiation for cell renewal. Both proliferation and differentiation occur in discrete zones. During the transient stages of postresectional adaptation the proliferative zone is more expansive and is at the same time associated with the presence of the growth stimulating activity. When the new steady state is reached the stimulating activity is no longer detectable and the discrete proliferating (crypt) and differentiating (villus) compartment are again observed. Thus it appears that the change from the steady state of the normal animal to the postresectional steady state takes place via an intermediate phase in which all the cells are capable of proliferating. The association of the growth stimula- ting activity with all the cells along the crypt villus axis during this intermediate phase strongly implies that it plays a role in this transition.

We wish to acknowledge Carole Garofalo, Thérèse Rouleau, and Anne Duhaime for their excellent technical assistance and Sylvie Tassé for secretarial assistance. This work was supported by an MRC grant to CLM.

\section{References}

1 Williamson, RCN. Intestinal adaptation. $N$ Engl J Med 1978; 298: 1393-1402, 1444-50.

2 Grey, VL, Morin CL. Evidence for a growth stimulating fraction in the rat proximal intestine after a small bowel resection. Gastroenterology 1985; 89: 1305-12.

3 Weiser MM. Intestinal epithelial cell surface membrane glycoprotein synthesis. I. An indicator of cellular differentiation. $J$ Biol Chem 1973; 248: 2536-41.

4 Grey VL, Garofalo C, Morin CL. Further characterization of a growth stimulating fraction in the proximal intestine after small bowel resection. Gastroenterology $1985 ; 88$ : 1406.

5 Handbook of Biochemistry: selected data for molecular biology. Chemical Rubber Co., C-71, 1971.

6 Klemperer HG, Haynes GR. Thymidine kinase in rat liver during development. Biochem $J$ 1968; 108: 541-6.

7 Breitman TR. The feedback inhibition of thymidine kinase. Biochem Biophys Acta 1963; 87: 153-5.

8 Eicholz A. Structural and functional organization of brush border of intestinal epithelial cells. III. Enzymatic activities and chemical composition of various functions of tris-disrupted brush borders. Biochem Biophys Acta 1967; 135: 475-90.

9 Lowry OH, Rosebrough NJ, Fan AL, Randall RJ. Protein measurement with folin phenol reagent. $J$ Biol Chem 1951; 193: 265-75.

10 Obertrop H, Nundy S, Malamud D, Malt RA. Onset of cell proliferation in the shortened gut. Rapid hyperplasia after jejunal resection. Gastroenterology 1977; 72: 26770.

11 Fortin-Magana R, Hurwitz R, Herbst JJ, Kretchmer N. Intestinal enzymes: indicators of proliferation and differentiation in the jejunum. Science 1969; 167: 16278. 